\section{Prevent Stunting Campaign: Dissemination of Health Information through Instagram}

\author{
Khusnul Khatimah , Laksmi \\ Universitas Indonesia
}

\section{Abstract}

Background of the study: Dissemination of health information that is not properly managed can result in a lack of public knowledge in maintaining their health and lead to serious health problems, such as stunting.

Purpose: The purpose of this study was to explore the use of Instagram as a tool for disseminating information related to stunting intervention in Indonesia.

Method: This study used content analysis method to identify and analyze 354 uploads with the hashtag \#cegahstunting on Instagram from August 2017 until December 2018.

Findings: Results showed that most campaign messages were directly related to health, which were dominated by content about preventive efforts aimed at general audience. Most uploaders were organizations, namely the government and non-profit institutions.

Conclusion: It is concluded that the role of individuals can be enhanced as relevant and trusted sources in creating and disseminating stunting-related information in Indonesia through social media. Information makers need to pay attention to the characteristics of the target group and the media used in order to create effective messages.

Keywords: health information dissemination, stunting, Instagram, social media

\section{Paper Type:}

Research Paper

Submitted 31 January 2019 Accepted 30 April 2019

Online 30 September 2019

* Correspondence: Khusnul Khatimah

E-mail:

Khusnul.khatimah@outlook.com

To cite this document:

Khatimah, K., Laksmi. (2019). Prevent stunting campaign: Dissemination of health

information through instagram. Record and Library Journal, 5 (1), 80 - 89. 


\section{Introduction}

Dissemination of health information through social media has become common in society. The use of social media changes the pattern of information dissemination into two-way interactions between organizations and individuals. Previously, information dissemination was carried out through private, formal, and non-digital communication between health information sources (such as public health-related organizations), medical staff, and the community. The flow of information took place in one direction, where the organization acted as a maker and disseminator of health information. Health professionals used this information to be redistributed to the public. In addition to changing the pattern of dissemination, the use of social media has also provided opportunities for individuals to play a more active role in the process. Individuals have equal opportunities with organizations as information makers and disseminators (Dumbrell \& Steele, 2013, p. 110).

Health information is one type of information that is considered important in everyday life. Unfortunately, this information is poorly managed, resulting in a lack of public knowledge in maintaining health and causing problems such as malnutrition and other health problems (Laksmi \& Fauziah, 2016, pp. 124-125). In 2014, the Global Nutrition Report included Indonesia in 17 countries that had nutritional problems, namely stunting (low height for age), wasting (low weight for height), and overweight in children below five years of age. Therefore, efforts to improve maternal and child nutrition are one of the four priority programs in the National Mid-Term Development Plan (RPJMN) for 2015-2019. One of the targets of the improvement in health and nutrition status was a decrease in the prevalence of stunting (being short and very short) in children under two years of age (28\%) in 2019 (Indonesia, 2014). This was partly triggered by the results of a study of Basic Health Research (Riskesdas) which showed that national stunting prevalence experienced an increase from 36.8\% (2007) to 37.2\% (2013) (RI Ministry of Health, 2013, p. 212 )

Stunting is a condition of failure to thrive in toddlers (under five years of age) due to chronic malnutrition, making the children's heights too short for their appropriate ages. In the Minister of Health Decree No. 1995 / MENKES / SK / XII / 2010 concerning the Anthropometric Standard for Assessment of Child Nutritional Status, the definition of stunting is based on body length index according to age. Toddlers are said to be short (stunted) or very short (severely stunted) if the results of a comparison between length or height and age are below normal (RI Ministry of Health, 2016, p. 1). Stunting can not only lead to morbidity and mortality in infants, but also disruption of intellectual abilities and can reduce the quality of human resources (Aryastami \& Tarigan, 2017, p. 234). Stunting results in a loss of $11 \%$ of GDP and reduces the income of adult workers by up to $20 \%$; thus, inhibiting economic growth and productivity (Deputy President of the Republic of Indonesia Secretariat, 2017, pp. 5-6).

Therefore, stunting is a health problem that needs to be taken seriously. Since 2012, the Government of Indonesia has designed two frameworks for stunting interventions, namely Specific Nutrition Interventions and Sensitive Nutrition Interventions. Specific Nutrition Interventions are interventions aimed at 1,000 first days of life (Hari Pertama Kehidupan, or HPK) targeting pregnant women, nursing mothers, and children aged 0-24 months. This intervention contributed to a $30 \%$ reduction in stunting. Meanwhile, Sensitive Nutrition Interventions are carried out through development activities outside of health issues and contributed to a $70 \%$ reduction in stunting. This activity involved various sectors, including community-based preventive acts to prevent stunting (Deputy Presidential Secretariat of the Republic of Indonesia, 2017, pp. 8-9).

In addition to designing an intervention framework, the government of Indonesia has established five pillars in handling stunting. One of them is in the form of a national campaign through both mass media and social media related to information dissemination with a focus on increasing understanding and changing behaviors. Based on the experiences in other countries, this was one of the strategies that could effectively reduce the prevalence of stunting (Deputy Secretariat of the Republic of Indonesia, 2017 , p. 14). The results of research conducted by Hall et al. (2018, p. 143) stated that maternal knowledge and awareness in Indonesia about stunting is relatively low. Most people never heard, read,

To cite this document:

Khatimah, K., Laksmi. (2019). Prevent stunting campaign: Dissemination of health

information through instagram. Record and Library Journal, 5 (1), 80 - 89. 
or found out about stunting. Therefore, the government and the community need to be involved in the dissemination of health information through available infrastructure and channels.

According to West et al. (2018, p. 1254), Posyandu, or maternal and child health services, was the main source of information ( $80 \%$ ) related to stunting used by mothers in rural Indonesia, followed by Puskesmas, or public health centers, $(31.7 \%)$, and the Internet $(16.9 \%)$. This is consistent with the study conducted by Saepuddin, Rizal, \& Rusmana (2017, p. 201) that the public perception of Posyandu was quite positive, not only as a place for health services, but also as a health information center. However, Posyandu is usually used by mothers with lower educational backgrounds. Meanwhile, mothers with higher educational backgrounds tend to choose the Internet as a source of information. The Internet also tends to be chosen by mothers who have given birth. Their educational background and experience make these mothers feel comfortable in accessing and evaluating the quality of information from online sources (West et al., 2018, p. 1257).

Social media have an important role in disseminating health information to the public (Salleh, Mohammed, Aziz, Hamzah, \& Zahari 2018, p. 1). This is supported by the growth rate of Internet and social media users in Indonesia. Based on the report by We Are Social \& Hootsuite (2019), in early January 2019 the number of Internet and social media users in Indonesia each reached 150 million people. This number increased by $13 \%$ for Internet users and $15 \%$ for social media users when compared to the 2018 report. A number of studies have been conducted to evaluate the use of social media as a means of disseminating health information (eg Nugroho, 2014; Rahmah, Huriati, \& Arbianingsih, 2018). However, most of the research focused its attention on the use of Facebook. On the other hand, research on the use of Instagram as a health dissemination tool was relatively small. The fact is Instagram in Indonesia is used by 62 million people or $23 \%$ of the total population (We Are Social \& Hootsuite, 2019). In addition, data in the form of types of health information disseminated through social media such as Instagram can easily be evaluated as feedback for the development of a more effective dissemination strategy. Based on this background, this research is aimed at exploring the use of Instagram as a tool for disseminating health information related to stunting treatment in Indonesia.

\section{Research Method}

This study uses a quantitative approach with the content analysis method. Krippendorff (2004, p. 18) defines content analysis as a research technique to make conclusions that can be replicated and validate texts (or other meaningful things) on the context of their uses. Meanwhile, according to Eriyanto (2011, p. 15), quantitative content analysis is a scientific research technique aimed at describing the characteristics of contents and attracting inferences from content. This study is not intended to test certain hypotheses, but rather to describe the characteristics of upload contents with the hashtag \#cegahstunting, or prevent stunting, on Instagram.

The research subjects were in the form of images and videos uploaded using the hashtag \#cegahstunting on Instagram from August 2017 to December 2018, totaling around 4,500 uploads. Of these, a sampling error of 5\% was determined and a confidence level of $95 \%$, so the total samples used in this study were 354 uploads.

Firstly, the researchers carefully collected and observed each sample which was randomly selected in this study. Based on these observations, the researcher made the coding categorization, namely the types of sources, messages, targets, media, and responses (as seen in Table 1).

Table 1. Coding Categories

\section{Category}

Source

\section{Description}

This category consists of 2 (two) units, namely organizations and individuals. The organizational unit consists of 4 (four) sub-units including the government (state agencies/ministries, local government, districts, and so on), health facilities (hospitals, health centers, clinics and the like), non-

To cite this document:

Khatimah, K., Laksmi. (2019). Prevent stunting campaign: Dissemination of health

information through instagram. Record and Library Journal, 5 (1), 80 - 89. 
profit institutions (communities, schools and the like)), as well as commercial institutions (industry, trade, consultants, and the like). Meanwhile, individual units consist of 5 (five) sub-units including parents, health professionals (doctors, nurses, midwives, and the like), other professionals (bloggers, photographers, motivators, and the like), community leaders (artists, religious leaders, local leaders, and the like), as well as students.

Message This category is divided into 2 (two) units, namely health and general. The health unit includes every message that is directly related to health topics, namely causes, symptoms, effects, and stunting prevention. On the other hand, general units consist of stunting-related messages that are not directly related to health topics, such as information about activities / events (seminars, counseling, and the like), donations, and promotions for commercial purposes.

Target Based on the message target, there are 4 (four) target units, namely mother, father, parent, and general. Messages specifically addressed to mothers are marked with information such as "bu", "moms", "emak" and the like, both in the images / videos uploaded and in the caption. It is likewise for the target unit of father. Uploads that do not contain specific information for the mother or father only, but are intended for parents, are included in the category of parents. On the other side, uploads not specifically addressed to the three units are grouped into general units.

Media There two types of media on Instagram: images and videos.

Response $\quad$ This category is marked by the total and average numbers of visitors who liked and commented on the images and videos.

Furthermore, each sample in the form of image / video uploads and captions were grouped based on the categories that had been made using coding sheets and processed using frequency tables. From the results of the calculation, the data was then analyzed and presented, and conclusions were made.

\section{Result and Discussion}

\section{Characteristics of \#cegahstunting Uploads}

Dissemination of health information related to the issue of stunting in Indonesia, among others, was done through Instagram. However, from 354 uploads on Instagram with the hashtag \#cegahstunting from August 2017 to December 2018, a total of 23 uploads (6\%) were not related to the stunting issue, so this data was not analyzed in this study. A total of 331 uploads $(94 \%)$, then, were divided into predetermined categories as shown in Table 2.

Table 2. Characteristics of Uploads with the hashtag \# cegahstunting on Instagram

\begin{tabular}{|c|c|c|c|}
\hline \multirow{2}{*}{$\begin{array}{l}\text { Category } \\
\text { Source }\end{array}$} & Unit & \multicolumn{2}{|c|}{ Sub-Unit } \\
\hline & Organization $(63 \% ; 207 / 331)$ & Non-profit organizations & $(25 \% ; 84 / 331)$ \\
\hline & & Government & $(21 \% ; 71 / 331)$ \\
\hline & & Commercial institutions & $(10 \% ; 33 / 331)$ \\
\hline & & Health providers & $(6 \% ; 19 / 331)$ \\
\hline
\end{tabular}

To cite this document:

Khatimah, K., Laksmi. (2019). Prevent stunting campaign: Dissemination of health

information through instagram. Record and Library Journal, 5 (1), 80 - 89. 
Khusnul Khatimah | Prevent stunting campaign: Dissemination of health information through instagram

\begin{tabular}{|c|c|c|c|}
\hline \multirow[t]{4}{*}{ Individual } & $(37 \% ; 124 / 331)$ & $\begin{array}{l}\text { Health professionals } \\
\text { Students/Univ. students }\end{array}$ & $\begin{array}{l}(11 \% ; 37 / 331) \\
(9 \% ; 31 / 331)\end{array}$ \\
\hline & & Other professionals & $(8 \% ; 26 / 331)$ \\
\hline & & Parents & $(8 \% ; 25 / 331)$ \\
\hline & & Community leaders & $(2 \% ; 5 / 331)$ \\
\hline \multirow[t]{4}{*}{ Health } & $(54 \% ; 218 / 406)$ & Preventive & $(42 \% ; 170 / 406)$ \\
\hline & & Effects & $(5 \% ; 22 / 406)$ \\
\hline & & Causes & $(5 \% ; 19 / 406)$ \\
\hline & & Symptoms & $(2 \% ; 7 / 406)$ \\
\hline \multirow[t]{3}{*}{ General } & $(46 \% ; 188 / 406)$ & Events & $(40 \% ; 164 / 406)$ \\
\hline & & Donation & $(4 \% ; 16 / 406)$ \\
\hline & & Commercial promotion & $(2 \% ; 8 / 406)$ \\
\hline
\end{tabular}

$\begin{array}{lll}\text { Target } & \text { General } & (86 \% ; 285 / 331) \\ & \text { Mothers } & (7 \% ; 23 / 331) \\ & \text { Parents } & (7 \% ; 22 / 331) \\ & \text { Fathers } & (0 \% ; 1 / 331)\end{array}$

$\begin{array}{lll}\text { Media } & \text { Images } & (90 \% ; 299 / 333) \\ & \text { Videos } & (10 \% ; 34 / 333)\end{array}$

Source: processed data

Based on Table 2, it is known that the uploader of the biggest number of contents with the hashtag \#cegahstunting are organizations (63\%; 207/331). Non-profit institutions $(25 \%$; 84/331) and government agencies $(21 \% ; 71 / 331)$ are the types of organizations that uploaded the most often with this hashtag. The presence of non-profit institutions as a source of information shows that the government is not alone in dealing with the issue of stunting in Indonesia. The government and other institutions can use social media as a tool for dissemination, discussion, and promotion in reaching the target communities (Laksmi \& Fauziah, 2016, p. 130).

In addition to organizations, individuals also play an active role as a source of health information dissemination. Social media allows individuals not only to be targeted by the recipient of the message, but to manage and share it with others in the network who are also interested in the issue. Thus, individuals help expand the range of dissemination emitted by the organization (Dumbrell \& Steele, 2013, p. 113).

Messages containing health topics $(54 \% ; 218 / 406)$ were uploaded more than general topics $(46 \% ; 188 / 406)$. Message types with the most uploaded health topics are related to how to prevent stunting $(42 \% ; 170 / 406)$. As many as $63(37 \%)$ of 170 uploads containing health information focused on 1,000 First Days of Life (HPK). While messages with general topics are dominated by messages related to stunting socialization events or activities $(40 \%$; 164/406), followed by donations $(4 \%$; $16 / 406)$, and commercial promotions $(2 \% ; 8 / 406)$. There are a number of uploads that have more than one message type.

Figure 1 shows an example of a message topic with the hashtag \#cegahstunting on Instagram. The types of messages that are directly related to health are indicated, among others, by uploading images containing information on preventive measures, causes, or effects of stunting. Meanwhile, the types of messages that are not directly related to health, for example, are pictures of programs or socialization activities on stunting issues and pictures of donation requests. In addition, a message was

To cite this document:

Khatimah, K., Laksmi. (2019). Prevent stunting campaign: Dissemination of health

information through instagram. Record and Library Journal, 5 (1), 80 - 89. 
found which was not at all related to the issue of stunting, such as a picture containing greetings on the birth of Pancasila (Five Pillars of Indonesia).

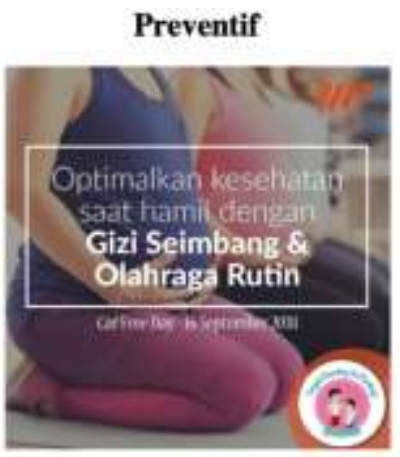

Acara

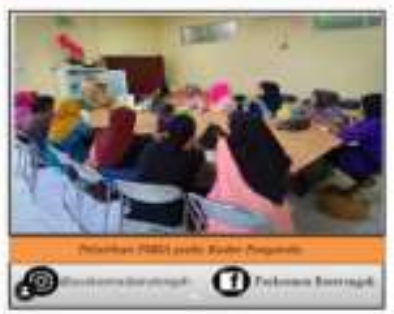

Penyebab

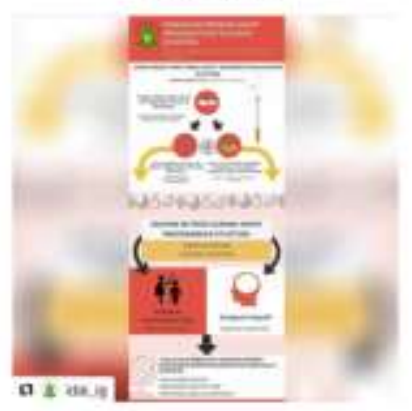

Donasi

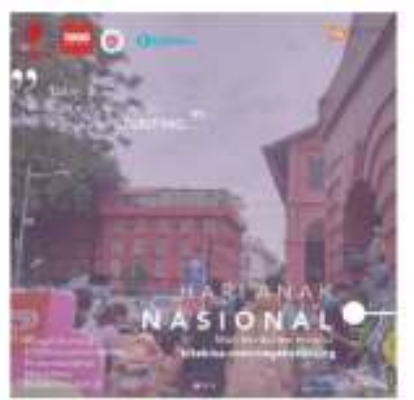

Efek

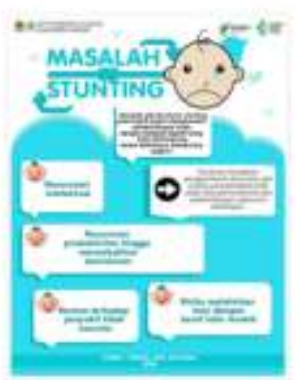

Tidak Berkaitan

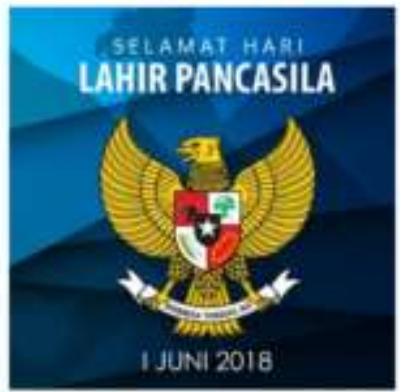

Figure 1. Examples of Message Topics with the Hashtag \#cegahstunting on Instagram

The large number of uploads about prevention of stunting can be attributed to the selection and use of \#cegahstunting as a hashtag However, in addition to prevention efforts, information about stunting such as effects, causes, and symptoms of stunting also needs to be conveyed so that people do not just understand how to prevent it, but also recognize what is meant by stunting and why stunting needs to be prevented.

In addition, the use of the term stunting can hinder the delivery of information to the public. Hall et al. (2018, p. 143) state that the term stunting is not well known by people in Indonesia, especially those living in rural areas, because it is not an Indonesian term. People generally refer stunting as being short, midget or dwarf. The choice of terms is one of the factors that determines the success of information dissemination.

The majority of the content uploaded is addressed to the general public $(86 \% ; 285 / 331)$, followed by mothers $(7 \%, 23 / 331)$ and parents $(7 \% ; 22 / 331)$. Of the 331 uploads, only 1 content was intended specifically for fathers. This might be because prevention of stunting is considered a joint mission so that messages are not specifically created and disseminated to parents (mother and father), but the general public. This is in line with the framework of the Stunting Intervention set by the government in which interventions targeting pregnant women, breastfeeding mothers, and children aged 0-24 months contributed to a 30\% reduction in stunting. The rest of the effort was carried by involving various sectors and community-based (Deputy President of the Republic of Indonesia, 2017, pp. 8-9).

A mother is usually a more active actor in finding health information. Compared to fathers, mothers use social media more often to find information about parenting, and to gain social and emotional support for issues related to parenting (Duggan, Lenhart, Lampe, \& Ellison, 2015). In this case, the involve ement of fathers in the prevention of stunting needs to be improved by creating messages specifically targeted at them.

The majority of the content is uploaded in the form of images $(90 \% ; 299 / 333)$. Instagram allows

To cite this document:

Khatimah, K., Laksmi. (2019). Prevent stunting campaign: Dissemination of health

information through instagram. Record and Library Journal, 5 (1), 80 - 89. 
users to upload both types of media (images and videos) in the same upload, so there were 2 (two) uploads with these characteristics. This finding shows that images become the favorite medium used by health information sources. However, global trends show that video content has increased in popularity in recent years. Moreover, nowadays videos can be produced more easily and at lower costs (Barysevich, 2018). Therefore, the use of video as a medium for disseminating health information can be considered.

Table 3 shows that each upload in the form of an image receives an average of 60 likes from visitors and has 3 comments. On the other hand, each upload in the form of a video gets an average of 61 likes and 1 comment.

Table 3. Levels of Response Toward Media

\begin{tabular}{ccccc}
\hline & \multicolumn{2}{c}{ Images $(90 \%, 299 / 333)$} & \multicolumn{2}{c}{ Videos $(10 \%, 34 / 333)$} \\
& Total & Average & Total & Average \\
\hline Likes & 18,074 & 60 & 2,058 & 61 \\
Comments & 1.033 & 3 & & 47 \\
\hline
\end{tabular}

Based on these data, it can be concluded that there is no major difference between the level of response to images and videos. However, this study found that messages delivered with videos tend to get more "likes", while messages in the form of images get more comments. For this reason, information makers can integrate image and video media as effective message containers.

\section{The Use of Instagram as a Health Information Dissemination Tool}

Dissemination of health information through Instagram can be done by organizations and individuals. Before the Internet era, the source of information dissemination was generally dominated by large organizations and came from government agencies (Dumbrell \& Steele, 2013, p. 113). However, this research shows that government organizations are no longer the main players in the dissemination of health information. Instagram provides opportunities for various other organizations, such as non-profit and commercial institutions to take part in the dissemination. According to Dumbrell \& Steele (2013, p. 113), these organizations have different goals and targets, so they are able to provide more specific health information and are aimed at more specific targets.

Even though most contents with hashtags \#cegahstunting are uploaded by organizations, this study found that individuals can be the sources of health information as well. Individuals with a professional background and education in the health sector are the biggest contributors to the content of \#cegahstunting on Instagram. Only $2 \%$ of all uploads come from community leaders. This is quite good, because in general when looking for health information, people rely on information made or issued by health professionals, such as doctors. Fishman, Greenberg, Bagga, Casarett, \& Propert (2018, p. 4) found that health articles from doctors or fellow patients tended to be chosen more than health articles from celebrities or religious leaders.

According to Hand, Kenne, Wolfram, Abram, \& Fleming (2016), health professionals generally use social media to gather information. In addition, Hazzam \& Lahrech (2018) stated that social media support communication among health professionals and can increase daily productivity. However, health professionals are skeptical that social media can be used to communicate and share information with patients, especially regarding privacy issues (Hand et al., 2016).

With the role of individuals as a source of health information, the chances of misinformation and disinformation increase (A1 Khaja, AlKhaja, \& Sequeira, 2018; Loeb et al., 2018; Sommariva, Vamos, Mantzarlis, Đào, \& Tyson, 2018). In the midst of such a situation, the role of health professionals as a

To cite this document:

Khatimah, K., Laksmi. (2019). Prevent stunting campaign: Dissemination of health

information through instagram. Record and Library Journal, 5 (1), 80 - 89. 
source of credible and relevant health information through social media is highly expected.

In addition to health professionals, individuals, such as parents, and other professionals can also play a role in providing reliable health information. Parents, for example, can share their experiences regarding nutrition and parenting. Other professionals, such as librarians, can take advantage of their ability to manage information (Zaid, 2017, p. 238). This is both an opportunity and a challenge because people in general do not use social media to share important information, such as health information and the like, but tend to self-expression (Laksmi \& Fauziah, 2016, p. 129). In addition, people tend not to share the health information they have because they consider that other people also know it (Kurniasih \& Sukaesih, 2017, p. 8).

In the dissemination of health information, the characteristics of the target are also important. Mothers are an important target in the dissemination of social media-based health information. Rosini \& Nurningsih $(2018$, p. 232) state that the search for health information through social media is more often done by married women, aged between 45 and 50 years, and have a D4 / S1 (university) education background. In addition to using social media with a high enough intensity, a mother is the main factor that determines a child's diet (Doub, Small, \& Birch, 2016, p. 301). Aryastami \& Tarigan (2017, p. 239) state that maternal knowledge, especially before pregnancy, is a strategic target in information dissemination in order to reduce the prevalence of stunting. However, in this study the amount of content specifically aimed at mothers tended to be small, namely 7\% (23/331). It is likewise with content addressed to fathers $(0 \% ; 1 / 331)$ and parents $(7 \%, 22 / 331)$. This study found that information aimed at parents was more related to how to prevent stunting, especially during the 1,000 First Day of Life (HPK) and activities such as campaigns, counseling, and socialization of stunting. This shows that the characteristics of the target determine the characteristics of the information created and disseminated. Information makers need to understand the behaviors, interests, and needs of the target groups.

In addition, the interaction pattern of information dissemination through Instagram can take place in two directions between the source and target information. However, this study shows that these interactions have not been carried out optimally. This is indicated by the low number of comments on uploads. For that, the information maker can create a message containing an invitation to the target to respond to the message. For example, it can be done by giving questions or allowing the target to ask further questions about the contents of the message.

\section{Conclusion}

This study confirms that the use of Instagram as a means of disseminating health information provides an opportunity for organizations and individuals to play an active role in creating and disseminating stunting-related information in Indonesia. Individual roles such as health professionals, information professionals, and parents can be enhanced as relevant and trusted sources of information in the dissemination of health information through social media.

In addition, information makers need to pay attention to the characteristics of the target group and the media used in order to create effective messages. Future research can be focused on the relationship between the characteristics of information through social media towards increasing knowledge and changing people's behaviors.

\section{References}

Al Khaja, K. A. J., AlKhaja, A. K., \& Sequeira, R. P. (2018). Drug information, misinformation, and disinformation on social media: a content analysis study. Journal of Public Health Policy, 39(3), 343-357. Retrieved From: https://doi.org/10.1057/s41271-018-0131-2

Aryastami, N. K., \& Tarigan, I. (2017). Kajian kebijakan dan penanggulangan masalah gizi stunting di Indonesia. Buletin Penelitian Kesehatan, 45(4), 233-240. Retrieved From : https://doi.org/10.22435/bpk.v45i4.7465.233-240

Barysevich, A. (2018). 5 Social media marketing trends that will dominate 2019. Retrieved from 
https://www.socialmediatoday.com/news/5-social-media-marketing-trends-that-will-dominate2019/543477/

Doub, A. E., Small, M., \& Birch, L. L. (2016). A call for research exploring social media influences on mothers' child feeding practices and childhood obesity risk. Appetite, 99, 298-305. Retrieved From: https://doi.org/10.1016/j.appet.2016.01.003

Duggan, M., Lenhart, A., Lampe, C., \& Ellison, N. B. (2015). Parents and social media. Retrieved from https://www.pewinternet.org/2015/07/16/parents-and-social-media/

Dumbrell, D., \& Steele, R. (2013). The changing nature of health information dissemination through the role of social media. Applied Mechanics and Materials, 414, 110-114. Retrieved From : https://doi.org/10.4028/www.scientific.net/AMM.411-414.110

Eriyanto. (2011). Analisis isi: Pengantar metodologi untuk penelitian ilmu komunikasi dan ilmu-ilmu sosial lainnya. Jakarta: Kencana.

Fishman, J., Greenberg, P., Bagga, M. B., Casarett, D., \& Propert, K. (2018). Comparing strategies for health information dissemination: Messengers that can help or hinder. American Journal of Health Promotion, 32(4), 932-938. Retrieved From : https://doi.org/10.1177/0890117117733780

Hall, C., Bennett, C., Crookston, B., Dearden, K., Hasan, M., Linehan, M., ... West, J. (2018). Maternal knowledge of stunting in rural Indonesia. International Journal of Child Health and Nutrition, 7(4), 139-145. Retrieved From : https://doi.org/10.6000/1929-4247.2018.07.04.2

Hand, R. K., Kenne, D., Wolfram, T. M., Abram, J. K., \& Fleming, M. (2016). Assessing the viability of social media for disseminating evidence-based nutrition practice guideline through content analysis of Twitter messages and health professional interviews: An observational study. Journal of Medical Internet Research, 18(11), e295. Retrieved From : https://doi.org/10.2196/jmir.5811

Hazzam, J., \& Lahrech, A. (2018). Health care professionals' social media behavior and the underlying factors of social media adoption and use: Quantitative study. Journal of Medical Internet Research, 20(11), e12035. Retrieved From : https://doi.org/10.2196/12035

Indonesia. (2014). Lampiran Peraturan Presiden Republik Indonesia Nomor 2 Tahun 2015 tentang Rencana Pembangunan Jangka Menengah Indonesia (RPJMN) 2015-2019.

Kementerian Kesehatan Republik Indonesia. (2013). Riset Kesehatan Dasar (Riskesdas) 2013. Jakarta: Kementerian Kesehatan RI.

Kementerian Kesehatan Republik Indonesia. (2016). Situasi balita pendek. Info Datin, 2442-7659. Retrieved From : https://doi.org/ISSN 2442-7659

Krippendorff, K. (2004). Content analysis: An introduction to its methodology (2nd Ed.). California: SAGE Publications.

Kurniasih, N., \& Sukaesih. (2017). Public health information behavior at flood-prone area in Bandung regency: A case study in Baleendah Village, Andir Village, Bojongsoang Village and Dayeuh Kolot Village. Record and Library Journal, 3(022), 1-9. Retrieved From : https://doi.org/10.20473/rlj.V3-I1.2017.1-9

Laksmi, \& Fauziah, K. (2016). Budaya informasi. Jakarta: ISIPII.

Loeb, S., Sengupta, S., Butaney, M., Macaluso Joseph N, J., Czarniecki, S. W., Robbins, R., ... Langford, A. (2018). Dissemination of misinformative and biased information about prostate cancer on YouTube. European Urology. Retrieved From : https://doi.org/10.1016/j.eururo.2018.10.056

Nugroho, S. V. (2014). Pengaruh pemberian materi kesehatan reproduksi melalui grup Facebook terhadap pengetahuan remaja. Jurnal Promkes, 2, 128-139.

Rahmah, M., Huriati, H., \& Arbianingsih, A. (2018). Perbedaan efektivitas pendidikan kesehatan media Facebook dan media leaflet terhadap motivasi berhenti merokok pada remaja. Journal of Islamic Nursing, 3(1), 62-70.

Rosini, R., \& Nurningsih, S. (2018). Pemanfaatan media sosial untuk pencarian dan komunikasi informasi kesehatan. Berkala Ilmu Perpustakaan Dan Informasi, 14(2), 226. Retrieved From : https://doi.org/10.22146/bip.33844

To cite this document:

Khatimah, K., Laksmi. (2019). Prevent stunting campaign: Dissemination of health

information through instagram. Record and Library Journal, 5 (1), 80 - 89. 
Saepuddin, E., Rizal, E., \& Rusmana, A. (2017). Peran posyandu sebagai pusat informasi kesehatan ibu dan anak. Record and Library Journal, 3(2), 201-208. Retrieved From : https://doi.org/10.20473/rlj.V3-I2.2017.201-208

Salleh, S. M., Mohammed, N. H., Aziz, N. U. A., Hamzah, S. F. M., \& Zahari, A. S. M. (2018). Exploring health communication in social media: A comparative review. Journal of Physics: Conference Series, 1019(1). Retrieved From : https://doi.org/10.1088/1742-6596/1019/1/012078

Sekretariat Wakil Presiden Republik Indonesia. (2017). 100 Kabupaten/kota prioritas untuk intervensi anak kerdil (stunting). Jakarta: Sekretariat Wakil Presiden RI.

Sommariva, S., Vamos, C., Mantzarlis, A., Đào, L. U.-L., \& Tyson, D. M. (2018). Spreading the (fake) news: Exploring health messages on social media and the implications for health professionals using a case study. American Journal of Health Education, 49(4), 246-255. Retrieved From : https://doi.org/10.1080/19325037.2018.1473178

We Are Social, \& Hootsuite. (2019). Digital 2019: Indonesia. Retrieved from https://www.slideshare.net/DataReportal/digital-2019-indonesia-january-2019-v01

West, J., Syafiq, A., Crookston, B., Bennett, C., Hasan, M. R., Dearden, K., ... Torres, S. (2018). Stunting-related knowledge: Exploring sources of and factors associated with accessing stuntingrelated knowledge among mothers in rural Indonesia. Health, 10(09), 1250-1260. Retrieved From : https://doi.org/10.4236/health.2018.109096

Zaid, Y. A. (2017). High blood pressure awareness among residents in Lagos State, Nigeria. Library Review, 66(4/5), 235-250. Retrieved From : https://doi.org/10.1108/lr-06-2016-0056

To cite this document:

Khatimah, K., Laksmi. (2019). Prevent stunting campaign: Dissemination of health

information through instagram. Record and Library Journal, 5 (1), 80 - 89. 